\title{
Integrating climate change and human impacts into marine spatial planning: A case study of threatened starfish species in Brazil
}

\author{
Nayla S. Patrizzi*, Ricardo Dobrovolski \\ Laboratório de Ecologia e Conservação, Instituto de Biologia, Universidade Federal da Bahia (UFBA), 40140-115, Salvador, Bahia, Brazil
}

\section{ART ICLE INFO}

\section{Keywords:}

Ecological niche modeling

Marine protected areas

Conservation planning

Climate change

Human impact

Zonation

\begin{abstract}
A B S T R A C T
Network expansion of marine protected areas in a changing world is a difficult task for conservation planners. Brazil experiences a combination of low and uneven protection of marine environmets, increasing anthropogenic pressures, climate change, and gaps in information regarding the geographical distribution of many species (Wallacean shortfall). Here, we addressed these issues and present a strategy for identifying priority marine areas for conservation in Brazil that would contribute to increasing species representation and achievement of conservation targets. Within this strategy, we accounted for (i) species range shifts due to climate change and their influence on species distribution, (ii) the lack of species geographical distribution data, and (iii) anthropic pressures on oceans. First, we built ecological niche models (ENMs) for 12 threatened starfish species in both present and future (2100) times using Maxent. We also quantified and mapped species range shifts. Second, we developed three conservation spatial solutions and compared the $10 \%$ top-ranked areas. The results showed that ENMs had a good performance in representing the distribution of species, even those that had few occurrence records. Our models forecasted a significant range expansion for the majority of species (10 out 12) by 2100 . We found that the priority sites covering the top-ranked $10 \%$ in the study area identified in ours conservation spatial solutions would protect between $10.41 \%$ and $15.88 \%$, on average, of suitable areas for the starfish species. Our results indicated priority sites for conservation less affected by anthropic pressures $(\sim 2 \%)$ when data on human impacts on oceans were incorporated into the spatial prioritization process. We identified a network of priority marine sites for conservation that minimized human influence and considered the effects of climate change on species distribution. We used threatened starfish species as a case study for illustrating our approach; however, such an approach could be applied to any taxonomic group, which supports the development of more effective conservation actions that represent biodiversity under such threats.
\end{abstract}

\section{Introduction}

Over recent decades, the diversity of life on Earth has been globally decreasing while pressures on biodiversity such as overexploitation and climate change effects have been increasing (Butchart et al., 2010). Species are disappearing fast and, if present trends continue, will soon reach unprecedented rates (Pimm et al., 2014). The need to conserve global biodiversity and ecosystems has never been greater and more widely accepted than it is today. The creation of well-designed and effectively managed protected areas systems is one of the most efficient strategies for conserving biodiversity (UNEP-WCMC and IUCN, 2016; Butchart et al., 2012). In the last few years, there has been increasing recognition of the conservation value of protected areas and, as a re- sult, many protected areas have been established worldwide. This increase in protected areas is related to several international initiatives that have been developed to reduce the current rate of biodiversity loss, such as the Convention on Biological Diversity (CBD) (CBD, 2010), the IUCN World Parks Congress (IUCN, 2014), and the Ramsar Convention (Ramsar, 2016). In 2010, parties to the CBD adopted a 10-year strategic plan to stem the loss of biological diversity and habitats, which is based on Aichi biodiversity targets (CBD,2010). Brazil is one of the signatory countries of this agreement and is committed to expanding its marine protected areas (MPAs) system by 2020 , saving at least $10 \%$ of its coastal and marine ecosystems - a core objective of the Aichi biodiversity target 11 .

Despite the well-known conservation value of MPAs for biodiversity, only $1.6 \%\left(56.734 \mathrm{~km}^{2}\right)$ of marine areas in Brazil are officially un-

\footnotetext{
* Corresponding author.

Email address: nayla.bio@gmail.com (N.S. Patrizzi)
} 
der some form of protection. A majority of these areas $(90.3 \%$ or $51.236 \mathrm{~km}^{2}$ ) are included in the Sustainable Uses group, which allow varying forms of use or extraction, with biodiversity protection only as a secondary objective. In contrast, Strict Protection MPAs, which have biodiversity protection as the primary objective and more restrictive rules that enable exclusively the indirect use of natural resources, represent only $0.2 \%\left(5.498 \mathrm{~km}^{2}\right)$ (CNUC/MMA, 2015). Besides being insufficient, Brazilian MPAs have very unequal distribution in their categories of protection ( $1.3 \%$ or $45.929 \mathrm{~km}^{2}$ corresponds to only 1 out of 12 management categories) as well as in the proportion of environments (Schiavetti et al., 2013) and are deficient in meeting conservation objectives for representation, connectivity, and risk-spread avoidance (Magris et al., 2013). There is, therefore, an urgent need to expand the existing MPA network in Brazil to safeguard marine biodiversity and ecosystems (Miloslavich et al., 2011).

The creation and designation of new MPAs in a changing world is not a trivial task. Oceans are getting warmer and becoming more acidic, and sea-level rise is accelerating (IPCC, 2014). Such climatically driven changes add complexity to the development of conservation actions (Kujala et al., 2013; Araújo et al., 2009), especially because they might lead to species range shifts (Monllor-Hurtado et al., 2017; Perry et al., 2005; Poloczanska et al., 2016). Uncertainties related to the response of species distribution to the effects of climate change have raised doubts about the effectiveness of MPAs and present a major challenge for conservation planning (Margules and Pressey, 2000). First, MPAs are geographically fixed, designed based on present climatic conditions, and do not take into account the geographical range shifts of species. Second, species are predicted to keep moving under future climate scenarios and might move out of MPAs (Hughes, 2000; Araújo et al., 2004). Particularly in marine environments, species range shifts related to a changing climate is happening very fast (an average rate of $19.0 \mathrm{~km}$ per year) (Sorte et al., 2010).

Furthermore, the threats imposed by climate change do not act in isolation; they also interact with threats associated with human activities. Marine biodiversity and environments are severely impacted by the effects of human pressures (Hoegh-Guldberg and Bruno, 2010; Harley et al., 2006). The effectiveness of MPAs can be altered by human activities developed outside their boundaries, such as unsustainable fishing and oil and gas exploration (Mazor et al., 2014), which can affect species and ecosystem functions within MPAs (McLeod et al., 2009). Such anthropic pressures on oceans have been mapped and quantified to offer guidance and support for conservation strategies (Halpern, 2008; Halpern et al., 2015). Excluding human activities in marine conservation planning could mean that anthropogenic threats to biodiversity are neglected (Mazor et al., 2014), which will result in plans that are unrealistic in the real world (Knight et al., 2008).

Thus, effective spatial conservation planning should consider species range shifts that are driven by climate change as well as human pressures when selecting areas for protection. Disregarding such factors will result in large areas of resource investments that will not be effective in the coming decades and will be inefficient for the conservation of many species, especially those that are endangered.

Ecological niche models (ENMs) have become an important tool to address climate change issues in conservation biology (Peterson et al., 2011) and have been widely applied in conservation planning (Lemes and Loyola, 2013; Guisan and Wilfried, 2005; Porfirio et al., 2014). ENMs predict the probability of environmental suitability for a species in an area (Carvalho et al., 2011) and can anticipate climate change influences on species distribution (Rodriguez et al., 2007). Such models are recognized not only as a valuable strategy to manage climate change (Loyola et al., 2013) but also to overcome the lack of knowledge regarding the geographical distribution of species (Elith et al., 2009), the so-called Wallacean shortfall (Lomolino et al., 2004), which has a serious consequence on conservation planning (Hortal et al., 2015).

In the present study, we propose a spatial prioritization approach to expand the Brazilian MPA network. We applied ENMs to overcome the Wallacean shortfall and predict the future distribution of species. We also generated three alternative spatial solutions based on (i) the current distribution of species, (ii) the future distribution of species, and (iii) information on human impacts on oceans for the expansion of the MPA network in Brazil. We also considered the current network of MPAs established in the region in our analyses. We utilized distribution data of the threatened starfish species as a case study, exemplifying how poorly known, highly sensitive to anthropogenic pressures, and generally underrepresented taxa might be included in spatial conservation plans.

\section{Methods}

\subsection{Study area}

Brazil contains one of the richest biodiversities in the world and is a member of a group that comprises 17 megadiverse countries (Cancun Declaration, 2002). Thus, developing approaches to design the best conservation solutions for this area are likely to contribute to the protection of a high proportion of the global biodiversity and influence conservation actions elsewhere (Ferreira et al., 2014). We focused the present study on the continental shelf of Brazil, which is the prolongation of its continental mass directed towards the ocean (Fig. 1). The width of the Brazilian continental shelf varies, being wider in the north of the country (maximum width of $300 \mathrm{~km}$ in the region of Amazonas), narrower in the northeast, and wider again in the southeast and southern region. The mean depth is $60 \mathrm{~m}$ in the flattest portion (internal platform), with an overall average of $128 \mathrm{~m}$ (Diegues, 1999). These shallow waters harbor the largest number and most threatened marine species and are highly suitable areas for the occurrence of threatened marine invertebrate species (Magris and Déstro, 2010). The continental shelf areas of Brazil are subject to both land-and ocean-based anthropogenic pressures and are under high human influence (Halpern et al., 2015).

\subsection{Species geographical distribution data}

We collected information on the geographical distributions of threatened starfish species from three online databases: SpeciesLink, the Ocean Biogeography Information System, and the Global Biodiversity Information Facility. We obtained 196 occurrence records for 12 threatened starfish species inhabiting the Brazilian coastal waters (Table S2). Records outside the study area were not included. We utilized starfish species to illustrate our approach because these organisms play important ecological roles in marine communities and are considered keystone species (Selig et al., 2014; Mills et al., 1993). Several species of commercial and ecological importance, such as fish and benthic crabs, feed on starfish species or are predated by them as juveniles (MMA, 2008).

These keystone species have extremely limited distributions and low potential for population recovery because they suffer from direct and indirect anthropogenic pressures (Table S1) and are particularly sensitive to ocean acidification and warming (Dupont et al., 2010; Sanford, 1999). Ocean acidification affects the swimming speed and mortality of sea urchin larvae (Dupont et al., 2008), which belongs to the same group of starfish, and the feeding habits and growth of juvenile starfish species (Apphelhans et al., 2014). Moreover, ocean warming increases the risk of starfish wasting disease (Eisenlord et al., 2016), which is a general description of a set of symptoms that vary slightly among species but generally start with behavioral changes, in- 


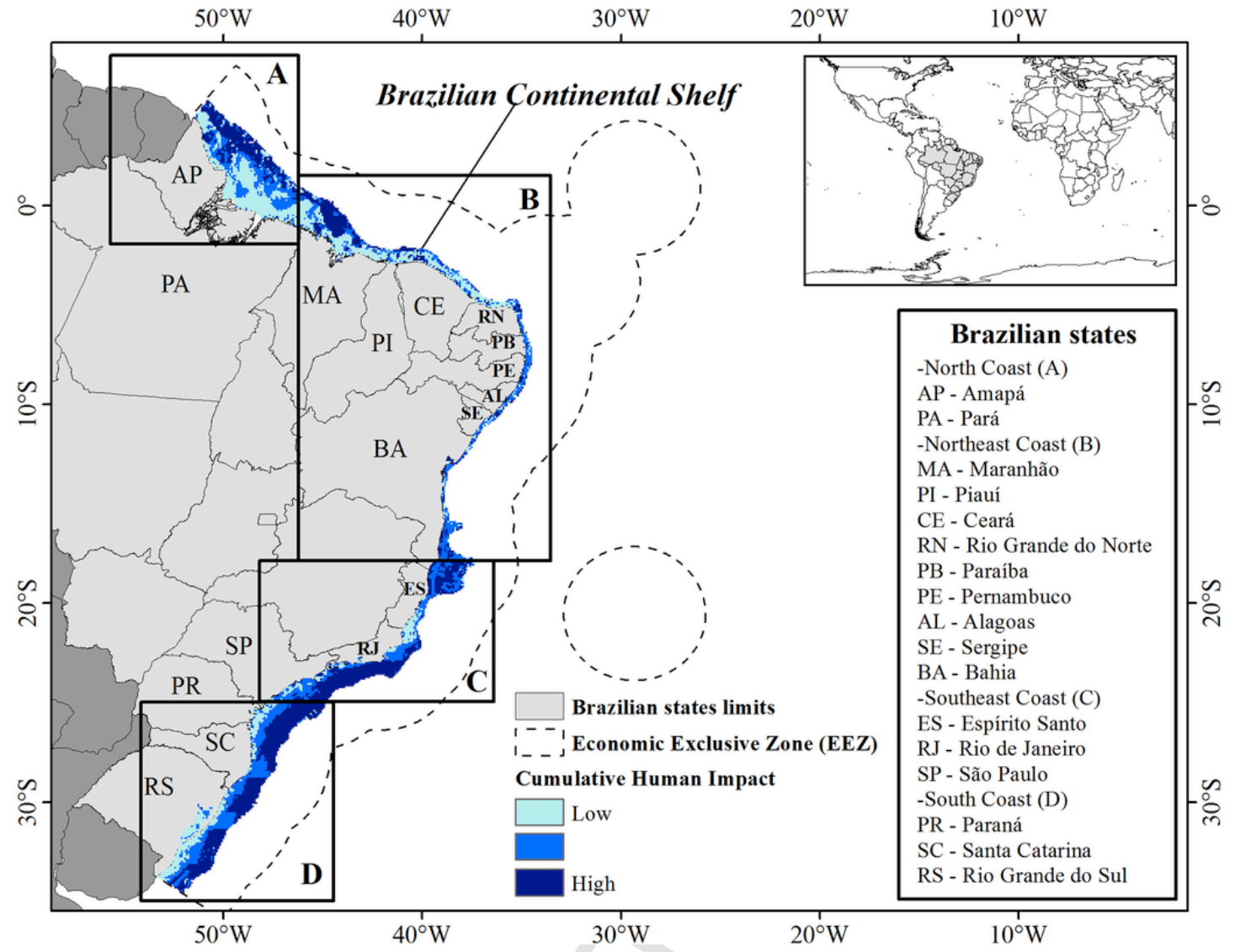

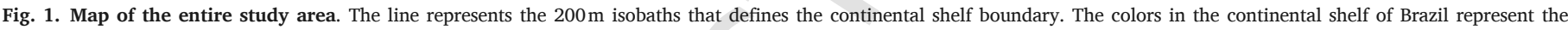

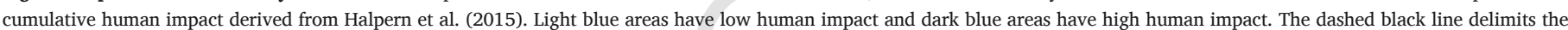

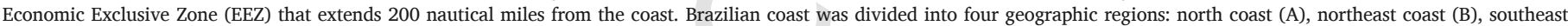
coast (C) and south coast (D). (For interpretation of the references to color in this figure legend, the reader is referred to the Web version of this article.)

cluding lethargy and limb curling, lesions, and end with animal death. This disease has recently devastated starfish species populations along the west coast of North America (Menge et al., 2016; Montecino-Latorre et al., 2016). Global warming-related range shifts of key species are of central importance for the conservation of biodiversity, since changes in the density of starfish species can affect the entire web of interactions, causing serious environmental damage and resulting in biodiversity and economic losses (MMA, 2008). Despite the ecological significance for marine ecosystems, starfish species are poorly represented in Brazilian MPAs (Magris and Déstro, 2010), highlighting the urgency of conservation action.

\subsection{Environmental data}

We compiled environmental data from the BIO-ORACLE (Tyberghein et al., 2012) and ETOPO5 (NOAA, 1988) databases. ETOPO5 is an Earth's surface model that integrates topography and ocean bathymetry data generated from a digital database of land elevation and sea with a resolution of 5 arcmin produced by the National Geophysical Data Center. BIO-ORACLE is a comprehensive global dataset of marine environmental rasters that is derived from monthly satellite imagery collected from various ocean observing satellite sensors (Aqua, Terra-MODIS, and SeaWiFS) with a resolution of 5 arcmin or $9.2 \mathrm{~km}$. Three future climatic scenarios that are derived from the Intergovernmental Panel on Climate Change and are represented by the UKMO-HadCM3 model, a coupled atmosphere-ocean general circulation model-B1 $(550 \mathrm{ppm})$, A1B $(720 \mathrm{ppm})$, and A2 (>800 ppm) -are available in BIO-ORACLE. These scenarios describe possible green- house gas emissions in the future and represent different socio-economic storylines, or developmental pathways, that human society might follow. The climatic scenarios are considered equally probable and are used, among others, as a basis for several climate projections (IPCC, 2000). Thus, the outputs from ENMs future projections can be interpreted as the likely range of climatic effects on species distribution by 2100.

A factor analysis was performed to select the environmental variables for ecological niche modeling (Terribile et al., 2012). Based on the factor analysis results, a subset of seven environmental layers were applied to all models: mean of diffuse attenuation (turbidity indicator of water), dissolved oxygen, maximum photosynthetically available radiation, $\mathrm{pH}$, silicate, salinity, and mean surface temperature of the sea.

\subsection{Ecological niche models}

Considering the low number of occurrence records for starfish species (Table S2) and the good performance in modeling species with limited data $(<25)$ (Pearson et al., 2007; Wisz et al., 2008), we applied the Maxent v 3.3.3 algorithm. This algorithm is based on the maximum entropy approach for modeling species niches and distributions and presented better performance than that of other algorithms, providing satisfactory results when few points of occurrence were available (Phillips et al., 2006)). From a set of environmental grids and georeferenced occurrence localities, the model expresses a probability distribution where each grid cell has a predicted suitability of conditions for the species. For each species, we modeled its ecological niche as a function of a subset of seven environmental variables described above for the current (405.91 ppm) (NOAA/ESRL, 2017) and future (550 ppm, 
$720 \mathrm{ppm}$, and $>800 \mathrm{ppm}$ ) climate scenarios (Tyberghein et al., 2012) projected to 2100 (Fig. 2).

A cross-validation procedure was applied and occurrence records were partitioned by randomly selecting $70 \%$ of the records as training data and $30 \%$ as testing data. We used an independent threshold, the area under the curve (AUC), to assess the performance of our model. The AUC is calculated by summing up the area under a receiver operating characteristic curve, which is a plot of sensitivity (also known as the true positive rate and representing absence of omission error) against 1 , and the specificity (also known as the false positive rate and representing commission error) for all possible thresholds. AUC values vary between 0 and 1 , with 0.5 being no better than random. We also used true skill statistics (TSS) as the dependent threshold to evaluate the performance of the models. TSS values equal to or lower than zero indicate models with performance no better than random. ENMs produce a continuous habitat suitability map (ranging from 0 to 1 per grid cell) as an outcome. Thus, areas where species have high suitability values usually provide more appropriate habitats and lower local probabilities of extinction than those areas where species have low suitability values. We generated 48 suitability maps, i.e., 12 suitability maps for each climatic scenario, which were later used as input data for spatial conservation prioritization analyses (Fig. 2). We considered only suitability values that were equal to or higher than 0.5 (threshold) in the prioritization analyses to avoid protecting areas of low conservation value.

\subsection{Spatial prioritization}

Spatial prioritization is a key step in systematic conservation planning and there are different decision support tools such as C-Plan (Pressey et al., 2009), Marxan (Ball et al., 2000), and Zonation (Moilanen et al., 2014) that are commonly used to identify priority areas for conservation. We used the Zonation framework and software, version 4.0, to derive priorities for the conservation of threatened starfish species. The main output from Zonation consists of a conservation priority ranked map of the study area, which is a raster file with the value in each cell indicating the relative conservation priority of that cell. These values are derived from the order of iterative cell ranking (removal). Each raster cell has a value between 0 and 1, meaning that values close to 0 are removed first (low relative conservation value and priority), whereas values close to 1 are retained until the end (high relative conservation value and priority) (Moilanen et al., 2014).

Here, we used the core-area Zonation (CAZ) cell removal rule to calculate the marginal loss of each cell. This variant prioritizes high-quality locations for all species in the final outcome. The CAZ cell removal rule is a better metric to protect endangered species because it represents the rarest species rather than the species richness (Moilanen et al., 2014). We developed three different conservation solutions using the CAZ cell removal rule: suitability maps derived from ENMs, data on the network of MPAs established in the region, and cumulative human impact on oceans.

The data on MPAs was obtained from the Ministry of the Environment (MMA, 2017) database. We extracted the MPAs by selecting areas belonging to both groups (Strict Protection and Sustainable Use). We overlapped the polygons of MPAs to our $0.5 \times 0.5^{\circ}$ grid and considered as "protected" only those cells where the MPA polygons covered more than $50 \%$ of the cell surface in our grid. This procedure was followed to maintain the real proportion of the Brazilian marine areas covered by MPAs. We then converted the MPAs data into a 5-arcmin resolution raster file and incorporated it as a hierarchical mask in the prioritization analyses. The so-called hierarchical mask is commonly used in spa- tial prioritization when developing an expansion for a pre-existing conservation area network (Lehtomäki et al., 2016). Zonation assigns a "mask level" to each grid cell and is retained until the end (high priority) cells with higher values indicate the priority for expansion of the MPAs. The algorithm considered cells that overlapped with pre-existing MPAs (all categories) as the top-ranked sites.

Further, we considered information on cumulative human impact derived from Halpern et al. (2015) for each grid cell of the study area in one of the solutions as a cost layer. When a cost layer is used, Zonation will assign the lowest ranks to areas that are of low ecological importance but that have high costs; conversely, the highest ranks will be assigned to ecologically important areas with low costs. This data subset consisted of 16 global anthropogenic drivers of change within marine ecosystems, weighted by the sensitivity of the ecosystems present in a grid cell to each of these drivers. The native resolution of this data is $1 \mathrm{~km}^{2}$. By the rule, cumulative data do not represent the future; however, future uses of the ocean will probably have the same spatial pattern. We correlated previous data of cumulative human impact (Halpern, 2008) and data from the most recent study published in 2015 in R software.

In the first solution, henceforth referred to as "current unconstrained priorities" (CUP), we utilized only the resulting suitability maps from the current climatic scenario and a mask layer. This solution identified the best sites for expanding and complementing the pre-existing MPA network in the current climate. In the second solution, "future unconstrained priorities" (FUP), we used the resulting suitability maps from both current and future climatic scenarios and a mask layer. This solution indicates the best areas for expansion of the MPA network in both current and future climates. In the third solution, "future constrained priorities" (FCP), we used the resulting suitability maps from current and future climatic scenarios, a mask layer, and information on human influence as a cost layer that attempted to solve the spatial conflict between threatened starfish conservation and human activities in coastal areas. This solution, in turn, identified the best sites to expand and complement the current network of MPAs in both current and future climates while avoiding highly human impacted areas (Fig. 2).

To facilitate comparisons among the geographical distribution of priority areas in the spatial solutions proposed, we presented our results delimitating the Brazilian coast into four geographical regions: north coast (A), northeast coast (B), southeast coast (C), and south coast (D) (Lima et al., 2002) (Fig. 1).

Further, we assessed how well each spatial solution preserved suitable habitats for the 12 threatened starfish species. For this analysis, we first converted the main output file of Zonation (hierarchical rank) and the suitability maps derived from ENMs into ASCII gridded xyz file format using the Translate (convert format) tool in the Raster menu of Quantum Gis. We generated files with 3 columns, with each line containing the $\mathrm{X}$ (longitude) and $\mathrm{Y}$ (latitude) coordinates of the center of the cell and the value of the cell. Thus, for each cell of the study area we had the value of the prioritization and the value of suitability. After that, we ordered the values of the cells from the hierarchical rank (highest to lowest) and expanded it to the values of habitat suitability of each species. We then calculated the percentage of suitable areas of each threatened starfish species included in each solution selecting only the top-ranked cells (10\%) of the study area (continental shelf). The $10 \%$ top-ranked areas of the seascape represented the percentage of species distribution that would be protected by each spatial solution proposed. Finally, we calculated the mean percentage of suitable areas for each species considering all possible future climatic scenarios and compared the conservation benefit of each spatial solution proposed. 

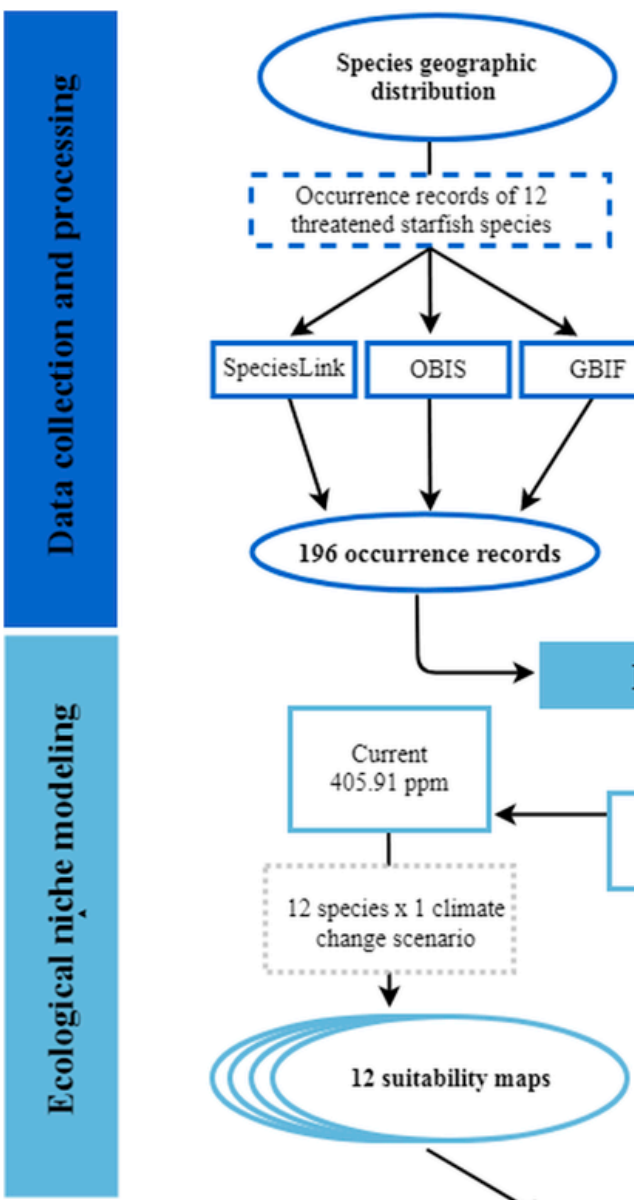

1 threatened starfish species
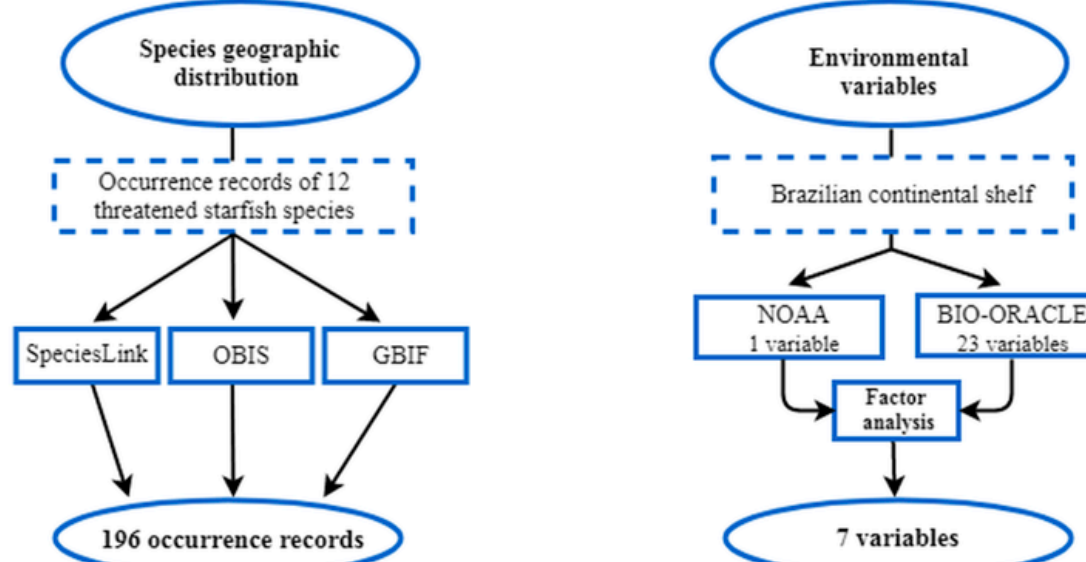

Brazilian continental shelf

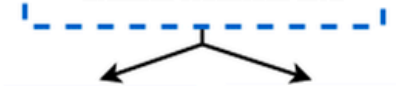

\begin{tabular}{c|c|c|}
\hline NOAA & BIO-ORACLE \\
1 variable & 23 .
\end{tabular}

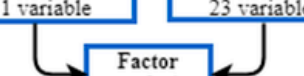

Factor
analysis

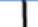

occurrence records

7 variables
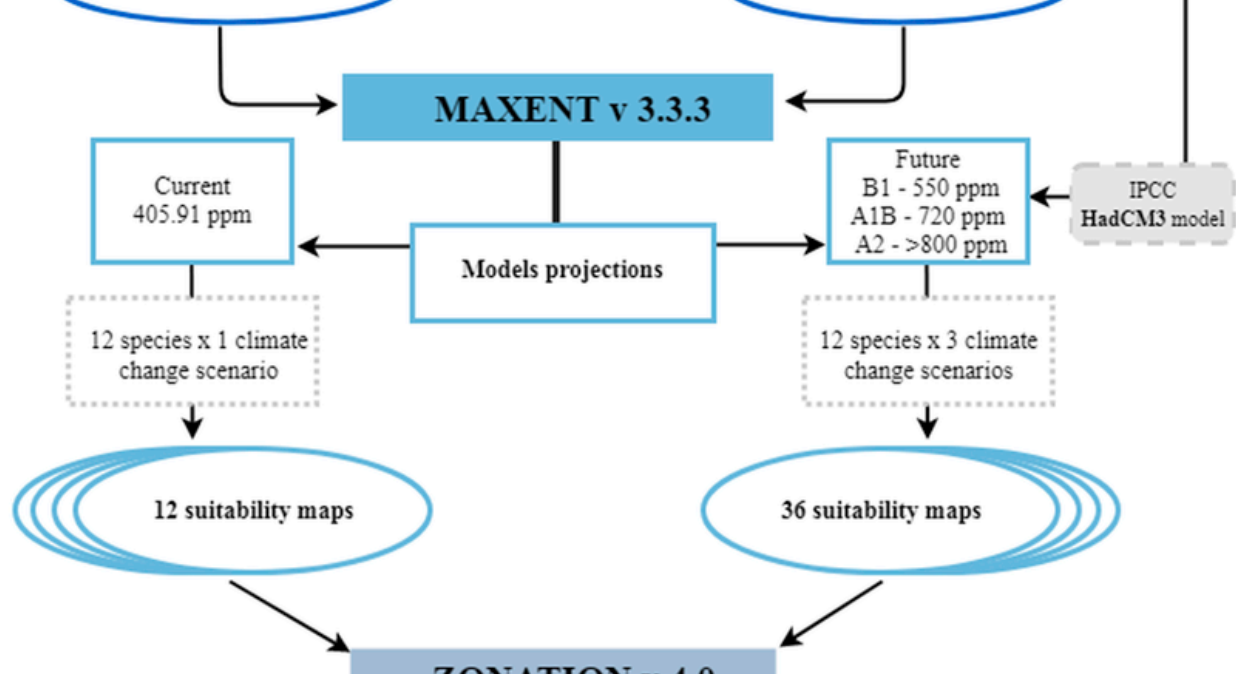

\section{ZONATION v 4.0}

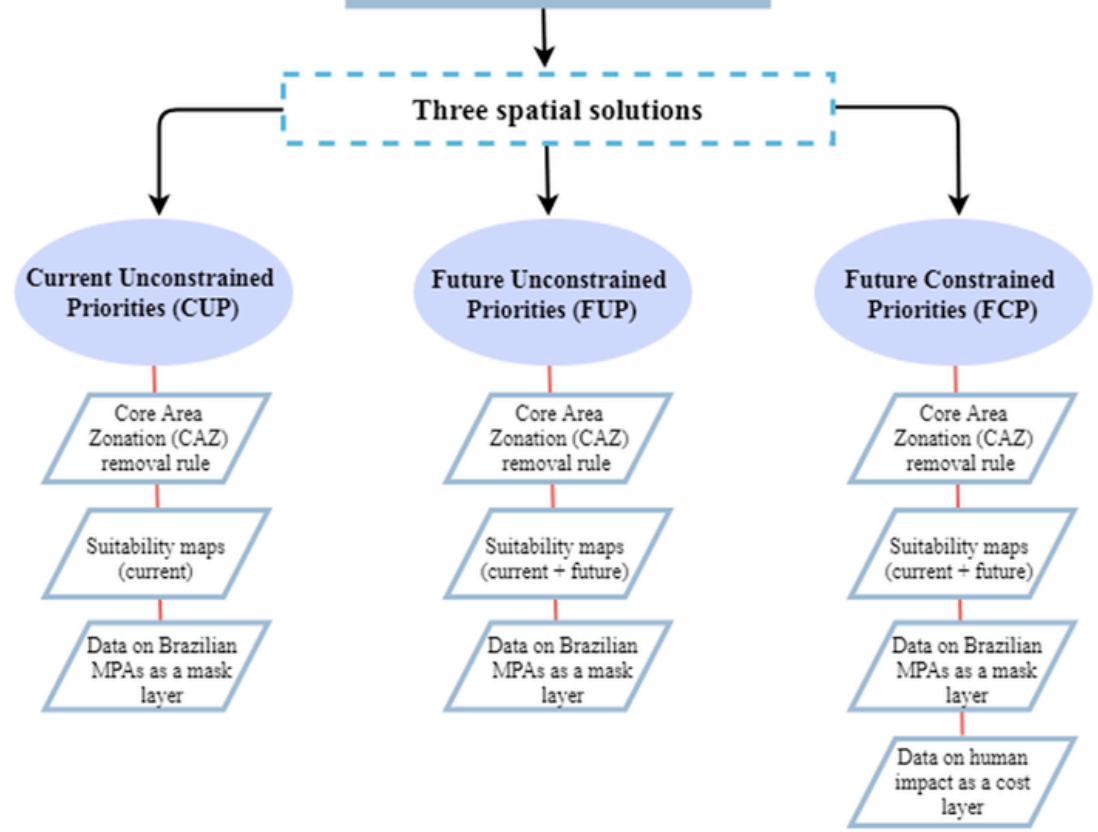

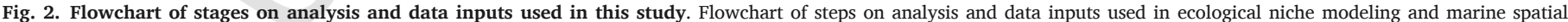
conservation planning approach developed. 


\section{Results}

\subsection{Ecological niche models}

In general, ENMs had a good performance representing the distribution of species based on the AUC and TSS values. For most species, TSS $(\mathrm{TSS} \pm \mathrm{SD}=0.67 \pm 0.15)$ and AUC $(0.93 \pm 0.04)$ values were relatively high, indicating a good model fit (Table 1).

Ten out of twelve species had a significant range expansion in all future climate scenarios (Table 1). The models predicted range expansion for Astropecten marginatus and Luidia senegalensis in the $550 \mathrm{ppm}$ and $720 \mathrm{ppm}$ scenarios followed by range contraction under the most severe climatic scenario ( $>800 \mathrm{ppm}$ ). Additionally, range contraction was forecasted for A. cingulatusin all scenarios and for Coscinasterias tenuispina in the $550 \mathrm{ppm}$ and $>800 \mathrm{ppm}$ scenarios. The geographical projections of future climatic scenarios showed an increase of suitable areas in the south and southeast regions of the Brazilian continental shelf for $75 \%$ of the species. However, geographical projections of a few species (25\%) showed an increase of suitable areas in the northern regions of the study area.

Our model projections revealed that high species richness occurred in the south region of the Brazilian continental shelf, both for the current time and for 2100 (see Figs. S2-S13). These areas were found to be not suitable for the occurrence of A. cingulatus and Echinaster echinophorus only. The distribution patterns of these two threatened starfish species correspond to the very south, north and northeast regions of the study area (see Fig. S3 and Fig. S8), respectively. Models showed the same suitability pattern for L. clathrata, C. tenuispina, and A. cingulatus. The southeast and south regions of the continental shelf are expected to have more suitable areas for threatened starfish species occurrence in the future than that of the north and northeast regions.

\subsection{Spatial prioritization}

We found a high correlation value $(r=0.95)$ between the two datasets for cumulative human impact in the study area (Fig. S1). This result showed that current uses of the ocean will probably have the same spatial pattern in the future. Thus, such data can be incorporated into the model to guide spatial prioritization approaches worldwide.

For practical purposes, here we show only the top $10 \%$ of cells that contributed the most to our conservation goal. The top $10 \%$ of cells was represented by 8829 cells or $747,286.56 \mathrm{~km}^{2}$. Currently, $7.7 \%$ (680 cells or $57,555.20 \mathrm{~km}^{2}$ ) of the Brazilian continental shelf is under some form of protection, a value that is significantly larger than that of the protected cells covering the exclusive economic zone.
All threatened starfish species would receive some measure of protection in the spatial conservation solutions proposed. Considering climate will not change, the CUP solution would be the most effective in protecting suitable areas for 11 of the 12 starfish species, followed by FUP and FCP. However, if climate changes the most effective solution would be FUP, followed by CUP and FCP. The FCP was the most effective solution for only one species (E. echinophorus). Regardless of the spatial solution and climatic scenarios, the $10 \%$ conservation target would, at best, cover $\sim 32 \%$ of suitable areas for E. brasiliensis and, at worst, cover on average $\sim 3 \%$ for $A$. cingulatus, which are the most and least protected species, respectively (Fig. 3).

Results from the CUP solution showed that the $10 \%$ conservation target would preserve an average of $15.88 \%$ (max $21.26 \%$, $\min 4.85 \%$ ) of suitable areas for the occurrence of threatened starfish species. The FUP solution would protect an average of $15.43 \%$ (max $25.54 \%$, min $5.49 \%)$, which is a slightly lower value $(0.45 \%)$ than that of the CUP solution. Incorporating anthropogenic threats into the prioritization solution (FCP) would reduce the average protection of suitable areas for the occurrence of threatened starfish species by $~ 5 \%$ (average $10.41 \%$, $\max 13.33 \%$, min $3.14 \%$ ) (Table 2).

The priority sites for investment in threatened starfish conservation that complement the current established network of MPAs identified in this study differed spatially. Considering the CUP solution (Fig. 4), potential sites for expanding and complementing the pre-existing MPAs were identified mostly in the southeast (Fig. 4-C) and south (Fig. 4-D) regions. A similar pattern of spatial priorities was found in the FUP solution (Fig. 5), as the southeast (Fig. 5-C) and south (Fig. 5-D) regions were the most important to protect. However, cells concentrated along the coast of Rio Grande do Sul (RS) and Paraná (PR) shifted to the south coast of the Rio de Janeiro (RJ) state. We achieved a compromised solution when we included data on human pressures in the analysis (Fig. 6). This latter spatial solution (FCP) indicated priority sites that were climatically suitable both in the present and future, and that are less affected by human activities. Different to the other two solutions, analysis based on the FCP solution indicated potential areas for protection in the north region of the study area (Fig. 6-A, compare similar areas in Figs. 4 and 5). Relevant sites were identified along the coast of Amapá (AP) and Pará (PA) (Fig. 6-A), the southern coast of Bahia (BA) (Fig. 6-B), Espírito Santo (ES), the northern coast of Rio de Janeiro (RJ) (Fig. 6-C), the coast of Parana (PR), and a few areas along the coast of Rio Grande do Sul (RS) (Fig. 6-D).

Comparing all three spatial solutions proposed, the top 10\% priorities for expanding pre-existing MPAs overlapped by $72.2 \%$ (Fig. S14). Although marked overlaps between priorities occurred in all solutions, the spatial configuration of priority areas of FCP indicated different sites for conservation when compared to the other two solutions. FCP priority areas were located further from the coast, and some priority

Table 1

AUC and TSS values of ENMs and the number of suitable cells of current and future scenarios $\left(\mathrm{CO}_{2}\right.$ concentration in ppm) considering the 0.5 threshold.

\begin{tabular}{|c|c|c|c|c|c|c|}
\hline Species & AUC & TSS & Current & Future & & \\
\hline & & & 405.91 & 550 & 720 & $>800$ \\
\hline Luidia senegalensis & 0.95 & 0.65 & 228 & 519 & 992 & 973 \\
\hline Astropecten marginatus & 0.96 & 0.66 & 164 & 355 & 769 & 728 \\
\hline Astropecten braziliensis & 0.98 & 0.88 & 91 & 628 & 1260 & 1416 \\
\hline Echinaster braziliensis & 0.99 & 0.89 & 34 & 109 & 179 & 202 \\
\hline Luidia ludwigii & 0.97 & 0.84 & 185 & 291 & 488 & 507 \\
\hline Linckia guildingii & 0.98 & 0.7 & 67 & 680 & 1560 & 1888 \\
\hline Oreaster reticulatus & 0.95 & 0.59 & 161 & 1186 & 1798 & 2548 \\
\hline Luidia clathrata & 0.91 & 0.36 & 489 & 585 & 758 & 774 \\
\hline Echinaster echinophorus & 0.87 & 0.63 & 3038 & 3484 & 3937 & 4572 \\
\hline Astropecten cingulatus & 0.89 & 0.68 & 996 & 757 & 653 & 627 \\
\hline Asterina stellifera & 0.98 & 0.78 & 194 & 553 & 1043 & 1101 \\
\hline Coscinasterias tenuispina & 0.84 & 0.48 & 2480 & 2113 & 2209 & 2194 \\
\hline
\end{tabular}



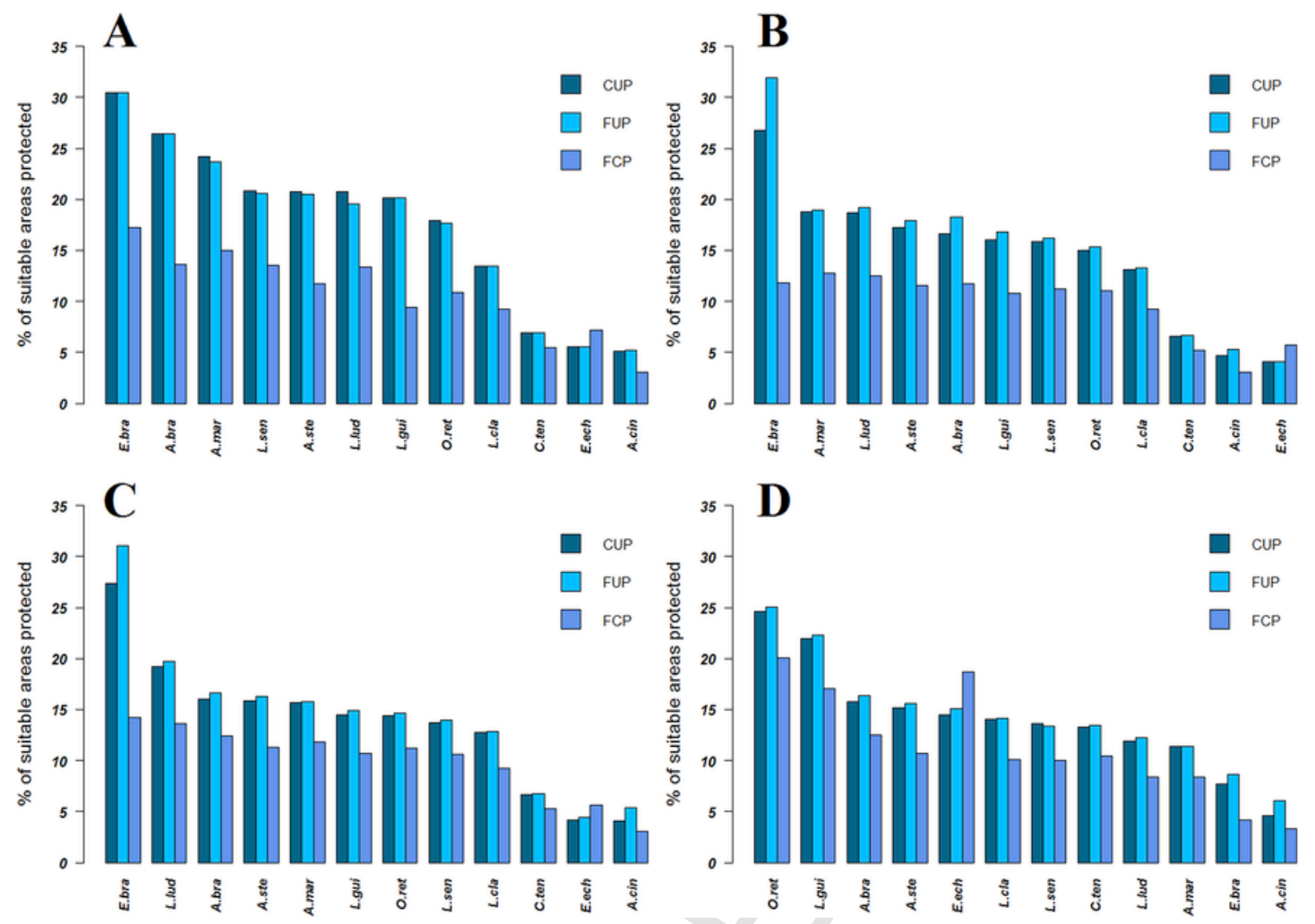

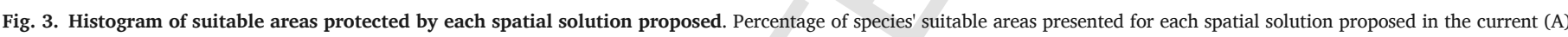

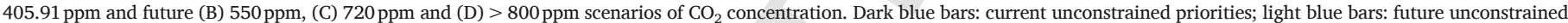
priorities; blue bars: future constrained priorities. (For interpretation of the references to color in this figure legend, the reader is referred to the Web version of this article.)

Table 2

Mean percentage of species' suitable areas protected by each spatial solution. Mean percentage of species' suitable areas protected by the spatial solution proposed in each scenario of $\mathrm{CO}_{2}$ concentration (405.91 ppm, 550ppm, $720 \mathrm{ppm}$ and $>800 \mathrm{ppm}$ ).

\begin{tabular}{llll}
\hline Species & Mean & & \\
\hline & CUP \% & FUP \% & FCP \% \\
\hline A. brasiliensis & 21.11 & 19.42 & 12.58 \\
A. cingulatus & 4.85 & 5.49 & 3.14 \\
A. marginatus & 17.78 & 17.45 & 12.00 \\
A. stellifera & 17.97 & 17.59 & 11.32 \\
C. tenuispina & 10.10 & 8.45 & 6.59 \\
E. brasiliensis & 19.11 & 25.54 & 11.85 \\
E. echinophorus & 10.01 & 7.26 & 9.30 \\
L. clathrata & 13.72 & 13.45 & 9.47 \\
L. guildingi & 21.03 & 18.56 & 12.01 \\
L. ludwigi & 16.34 & 17.69 & 11.99 \\
L. senegalensis & 17.22 & 16.02 & 11.33 \\
O. reticulatus & 21.26 & 18.19 & 13.33 \\
Mean & $\mathbf{1 5 . 8 8}$ & $\mathbf{1 5 . 4 3}$ & $\mathbf{1 0 . 4 1}$ \\
\hline
\end{tabular}

sites shifted from the southern to the northern regions (Figs. 4-6). Moreover, the sum of cumulative human impacts was lower $(5.4 \%)$ than that in the CUP $(7.6 \%)$ and FUP $(8.1 \%)$ solutions.

\section{Discussion}

\subsection{Ecological niche models}

Based on the AUC and TSS values, the models in the present study generated reasonable predictions of potentially suitable areas for the threatened starfish species analyzed, even for those species with few records $(<10)$. Comparable findings were obtained in other studies that have predicted the distribution of species with a relatively small number of records using a similar approach (Kumar and Stohlgren, 2009; Papes and Gaubert, 2007; Hernandez et al., 2006). Additionally, our results showed that most starfish species would likely undergo relevant range expansion southwards in the future. Marine species respond to ocean warming by shifting their latitudinal range e.g. (Parmesan, 2006; Perry et al., 2005), as individuals track favorable climatic conditions. Consequently, local extinction and invasions might occur, rearranging the distribution of species that contribute to the functioning of natural ecosystems and the services they provide. As keystone species, a large decrease or increase in starfish populations has the potential to greatly alter marine ecosystems. Furthermore, starfish range shifts might affect fishing activities and have socio-economic effects on coastal communities.

Despite being considered the best tool available to address climate change effects on future distributions of species, ENMs are fraught with uncertainties. Such models do not consider biotic interactions, evolutionary changes, and dispersal of species, which generate doubts about the accuracy of species distribution. Yet, climatic scenarios that are used to generate the future predictions in ENMs can also contribute to model uncertainty (Heikkinen et al., 2006; Pearson and Dawson, 2003). Biodiversity data biases also influence ENMs (Hortal et al., 2015). For example, some regions along the Brazilian coast (south and southeast) have been better sampled than others because of well-established research groups and the large number of samples taken during oceanographic expeditions (Amaral and Jablonski, 2005). If distribution data is unevenly distributed, ENMs can generate unrealistic results (Rocchini et al., 2011). However, such models are still the best strategy for obtaining data that will be applied to conservation planning (Hannah et al., 2007). Nowadays, MPAs are established mostly based on current species distribution data, which might mean they are inadequate to protect species in the future. Anticipating species distribution responses to future climatic scenarios would assist with the develop- 

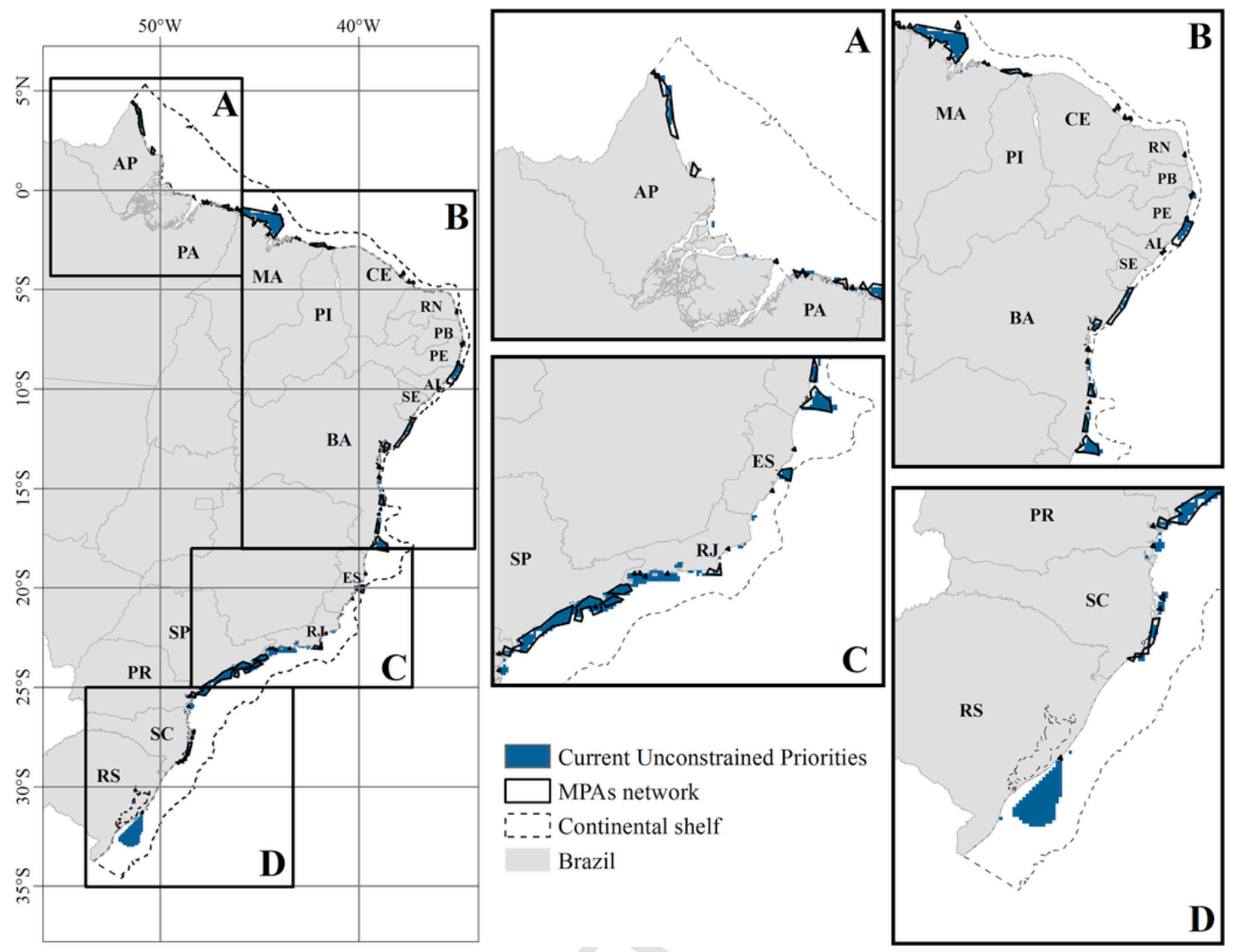

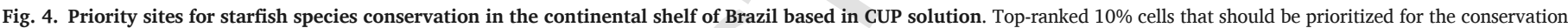

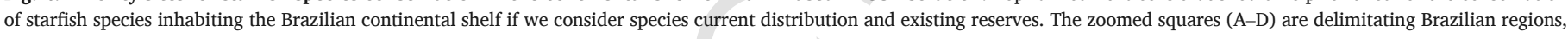
north, northeast, southeast and south respectively.

ment of more effective spatial conservation plans. Therefore, ENMs cope with the barrier imposed by climate change and the scarcity of distribution data of many species. Marine spatial conservation plans would certainly benefit from ENM projections, and thus support the protection of rare or threatened species more effectively.

\subsection{Spatial prioritization}

Our findings showed that the best $10 \%$ of the spatial conservation solutions proposed in the present study would assure an average coverage of $15.88 \%, 15.43 \%$, and $10.41 \%$ of suitable areas for threatened starfish species in the CUP, FUP, and FCP solutions, respectively. In addition, our results indentified priority sites for conservation less affected by anthropic pressures $(\sim 2 \%)$ when data on human impacts on oceans were incorporated into the spatial prioritization process

The solution based only in the current time (CUP) was better in terms of species representativeness than that of the FUP and FCP solutions. This can be explained by the fact that the network of MPAs established in Brazil was created considering only the known geographical distribution of species. Hence, the geographical distribution of the priority areas was affected by the inclusion of MPAs because the algorithm identified areas to complement the pre-existing MPAs network and was not free to determine which areas were better to protect based only on species distribution information. Moreover, because of assigning high costs to impacted sites in the analyzes, the FCP solution might result in only protecting areas with the least potential for human uses but also be less suitable (Fig. 6) for species occurrence and persistence. Similar to other marine conservation plans developed recently, we found that the inclusion of human pressures can significantly alter spa- tial priorities (Mazor et al., 2014; Vilar et al., 2015). In addition, the cumulative human impacts data was derived from a global dataset in which data quality and spatial scale are heterogeneous worldwide and assumed that pressures will remain in the same regions they are currently mapped in; however, pressures can change. From the previous study until now, nearly $66 \%$ of the ocean has experienced increases in human pressures over the 5-year study span and increases tended to be located in tropical, subtropical, and coastal regions (Halpern et al., 2015). Nevertheless, this will have little effect in our spatial solutions because a high correlation was found between both cumulative human impacts datasets. Further, the CUP and FUP spatial solutions identified potential priority areas in the south region, which is less protected than the north region (Halpern et al., 2015). Such sites will probably be more suitable for most species but will also be more affected by human uses by 2100 (Figs. 4 and 5). Some of these uses (e.g., fishing, pollution, and habitat destruction) are recognized as major threats to starfish species conservation (MMA, 2008; Amaral and Jablonski, 2005). Therefore, investing in conservation plans that do not consider such pressures would be problematic, since the majority of MPAs in Brazil permit a wide range of uses and threats are not contained and drift easily across the unmarked boundaries of MPAs. Thus, conservation plans that incorporate such pressures have a greater potential of implementation success, mitigate conflict with other uses, and reduce threats to biodiversity (Mazor et al., 2014).

We found that $7.7 \%$ of the Brazilian continental shelf is already under legal protection. Although there is a higher percentage of marine areas protected along the continental shelf of Brazil than that in the exclusive economic zone (1.6\%), most of these areas allow different types and intensities of human interference, with the conservation of biodiversity being a secondary objective, and thus might create a false con- 

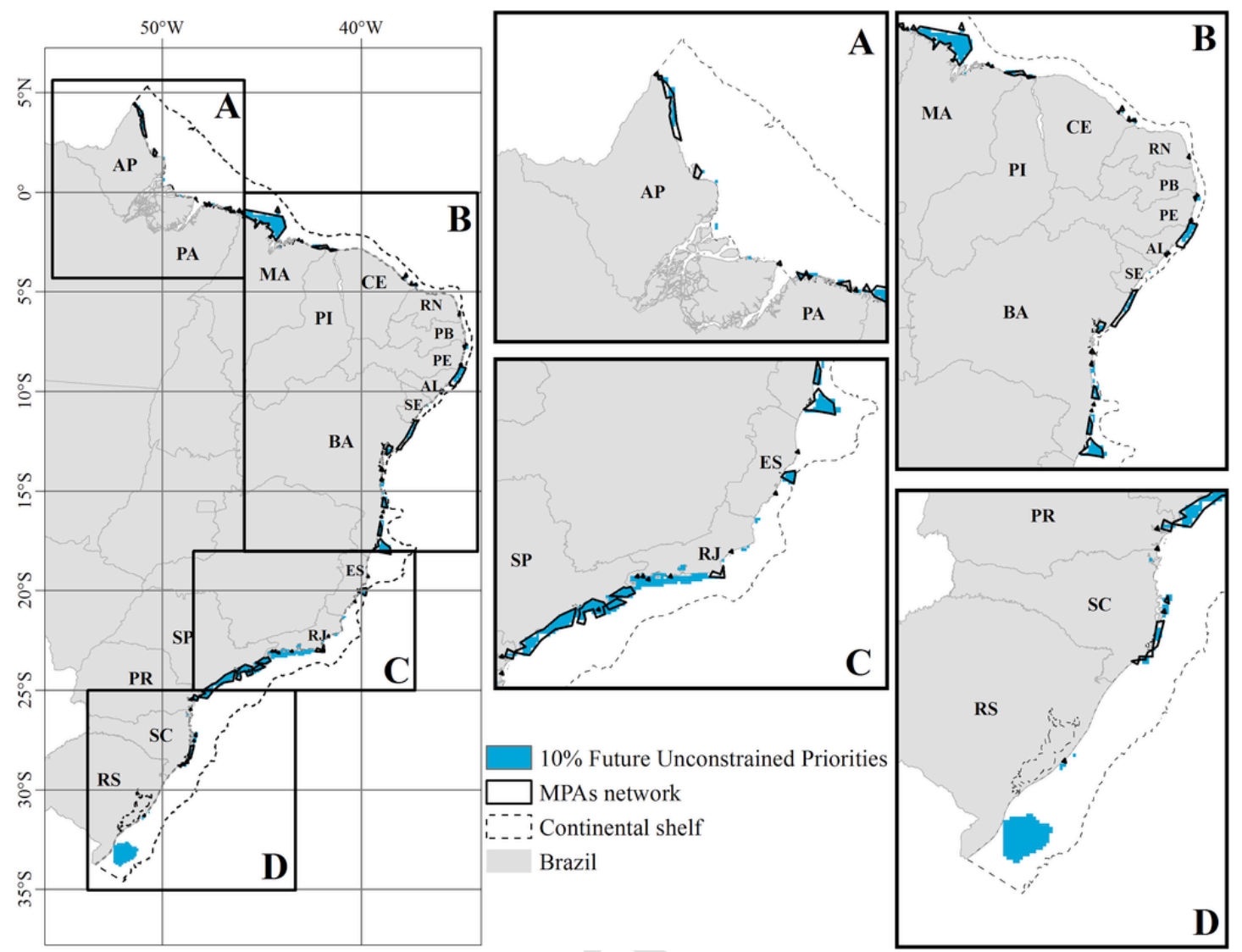

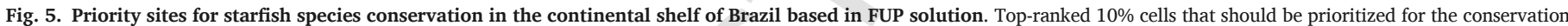

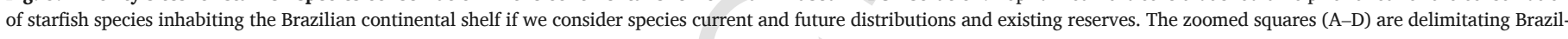
ian regions, north, northeast, southeast and south respectively.

servation impression. In addition, a management plan that establishes the norms, restrictions of use, actions to be developed, and management of the natural resources must be developed within the next 5 years; however, many MPAs of sustainable uses still lack such documents, resulting in MPAs that are more vulnerable to predatory anthropogenic activities. Only with a proper management plan, the elaboration of the limits of explotation area will be clearly defined (MMA, 2018). Many anthropic activities such as illegal fisheries, overexploitation of resources, and habitat modification inside MPA boundaries from both management categories are still being reported (Wahrlich, 1999; Dutra et al., 2011; Spínola et al., 2014; Soares et al., 2011). Furthermore, it is increasingly recognized that many protected areas undergo downgrading, downsizing, and/or degazettement (Mascia and Pailler, 2011) because of social, economic, and political interests. Downgrading events are already occurring in Brazilian marine waters, such as the recategorization of the Arvoredo Biological Reserve and Taim Ecological Station (strictly prohibits public visitation) to National Parks (allows public visitation) ( (Mascia et al., 2012). Thus, the designation of a MPA is one step towards effective protection; however, alone it is insufficient for conservation outcomes (Boonzaier and Pauly, 2016). Such designation provides a simple metric that is communicable and quantifiable, and it has thus been chosen by the international community as an indicator of conservation progress.

Since targets to measure conservation progress were set (i.e., Aichi biodiversity target 11), conservationists have been discussing how much is enough to effectively protect the oceans. According to recent studies, the $10 \%$ target is too low and might not be enough to meet MPA objectives (O'Leary et al., 2016) or maintain viable populations of many species and has been adopted only for political purposes (Soulé and Sanjayan, 1998). In 2014, the World Parks Congress (IUCN, 2014) recommended that countries should aim for $30 \%$ coverage of strictly protected MPAs. This is well above the United Nations target of $10 \%$ protection by 2020, set under the CBD (CBD, 2010). Regardless, the achievement of conservation targets is still very challenging. First, Brazil has shown a slow rate of addition to the MPA system during the last 15 years (Magris et al., 2013) and, considering such a rate, it is estimated to take another 25 years to achieve the Aichi biodiversity target 11 . Second, the degree to which the implementation of MPAs in Brazil is protecting biodiversity is still very low. Third, despite relevant past efforts to enhance the role of protected areas in Brazil, such as the construction and designation of the National System of Conservation Units and the National Program on Protected Areas, many management shortcomings (e.g., poor management within individual MPAs and financial shortages creating structural problems) are identified in the Brazilian MPA system. If such issues are not addressed, Brazil's international marine biodiversity commitments will not be achieved (Gerhardinger et al., 2011). Aichi biodiversity target 11 addresses not only area because MPAs should also be "effectively, equitably managed, ecologically representative and satisfactorily interconnected" protected area systems. Thus, managers and policy makers should stop racing towards a certain number and instead must truly fulfill what was agreed upon in the first place: to improve the status of biodiversity by safeguarding ecosystems, species, and genetic diversity.

\section{Conclusions}

Conservation planners are challenged by the way that the world is changing. The establishment of new MPAs in megadiverse and develop- 

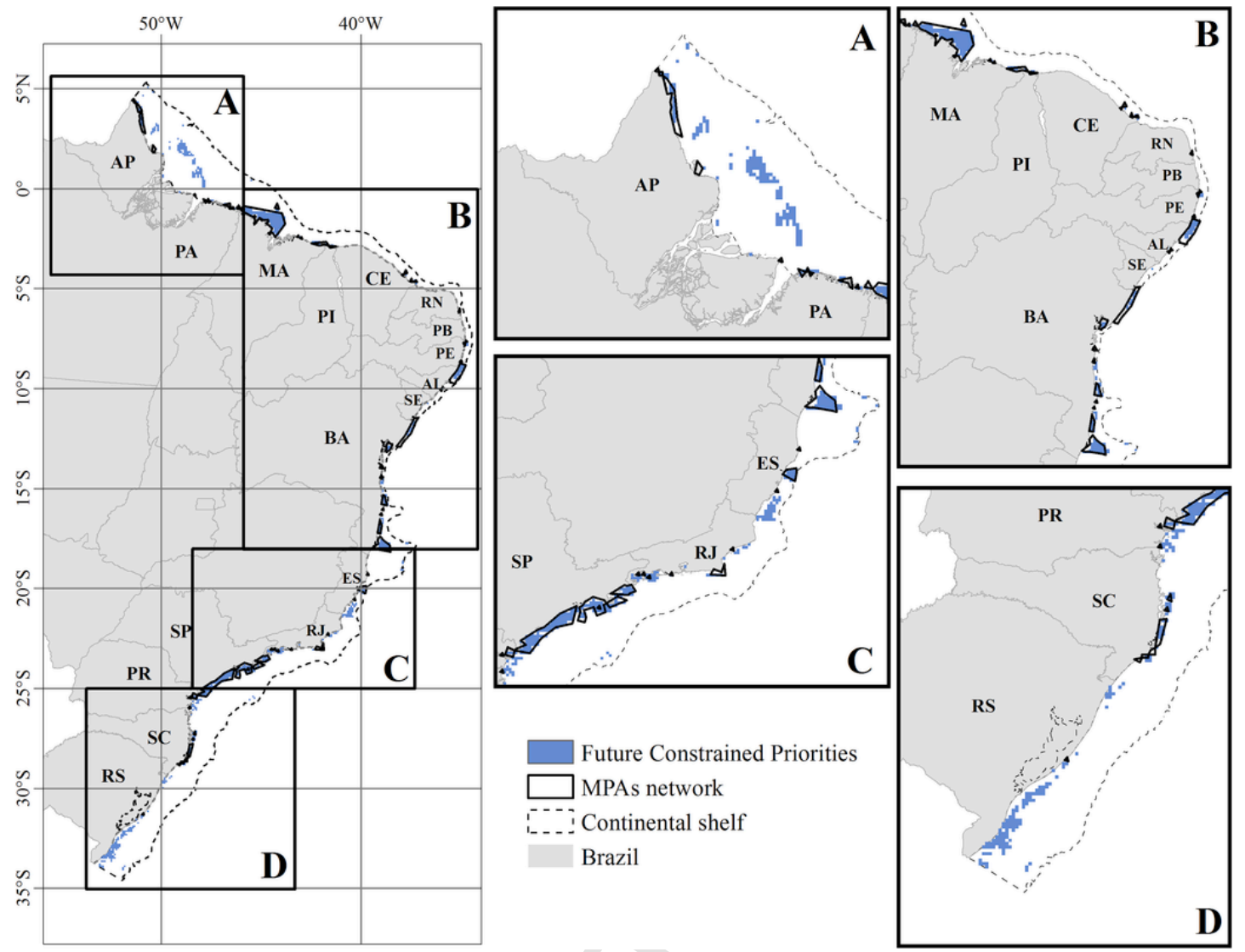

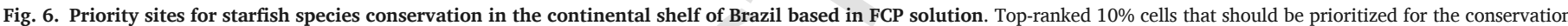

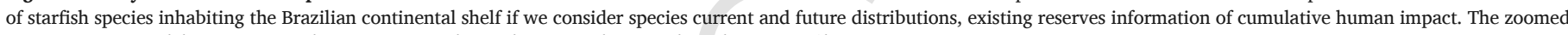
squares (A-D) are delimitating Brazilian regions, north, northeast, southeast and south respectively.

ing countries, such as Brazil, is not simple. The combination of low and uneven protection within Brazilian marine waters, increasing anthropogenic pressures, climate change, and gaps in the geographical distribution of many species add complexity to conservation actions.

Climate change and human pressures can drastically alter the distribution of priority areas for conservation. Species might shift their geographical distribution to track more favorable conditions in response to climate change. Consequently, local extinctions and invasions might occur, rearranging the distribution of species that contribute to the functioning of natural ecosystems and the services they provide. Anticipating future shifts in the geographical distribution of species can help define where MPAs should be implemented, improve effectiveness in the face of climate change and provide collaboration with species persistence. In addition, data on anthropic impacts on oceans might reduce the conflicts of interests between conservation and economic growth. Such conflicts can be problematic and may be contribute to the inefficiency of a MPA, i.e. economic activities, such as fishing, might occur in an area where most of the fish diversity is found. If a MPA was created in a very conflicting area, it would have, among others, much more hostile surrounding habitats and would also need a lot of police and management effort. Furthermore, the use of such data avoided highly affected areas, minimizing human pressures on priority sites,. which might result in more realistic spatial conservation plans that are more effective in the real world.

We used threatened starfish species as a case study for illustrating our approach; however, this could be applied to any taxonomic group, supporting the development of effective conservation actions that represent biodiversity under such threats. Spatial planning tools were designed to support users to decide on the location and configuration of conservation areas and should not exclude human expertise. Thus, the priority areas for protection identified here can be thought of as an exploratory approach that can be improved and debated by authorities, conservationists, and stakeholders.

Results from the present study, therefore, contribute to the expansion of priority areas in Brazil, which is necessary for protecting the species evaluated here, but also exemplifies how the available tools and data can assist in obtaining the best benefits for biodiversity at the same time as expanding MPAs.

\section{Acknowledgements}

This paper is a contribution of the INCT in Ecology, Evolution and Biodiversity Conservation founded by MCTIC/CNPq/FAPEG (465610/ 2014-5). RD is supported by CNPq (461665/2014-0), and FAPESB (JCB0051/2016). NSP was supported by CAPES.

\section{Appendix A. Supplementary data}

Supplementary data related to this article can be found at https:// doi.org/10.1016/j.ocecoaman.2018.05.003.

\section{References}

Amaral A.C.Z. and Jablonski S., 2005. , Conservation of marine and coastal biodiversity in Brazil. Conserv. Biol. 19, 625-631. https://doi.org/10.1111/j.1523-1739.2005. 00692.x.

Apphelhans, Y.S., Thomsen, J., Opitz, S., Pansch, C., Melzner, F., Wahl, M., 2014.. Juveline sea stars exposed to acidification decrease feeding and growth with no acclimation potential. Mar. Ecol. Prog. Ser. 509, 227-239. https://doi.org/10.3354/meps10884. 
Araújo, M.B., Cabeza, M., Thuiller, W., Hannah, L., Williams, P.H.. 2004. Would climate change drive species out of reserves? An assessment of existing reserves election methods. Glob. Change Biol. 10, 1618-1626.

Araújo M.B., 2009. . Climate change and spatial conservation planning. In: Moilanen, A., Wilson, K.A., Possingham, H.P. (Eds.), Spatial Conservation Prioritization: Quantitative Methods and Computational ToolsOxford University Press, USA, pp. pp. 172-184.

Ball, I.and Possingham, H., 2000. Marxan (v.1.8.2): . Marine reserve design using spatially explicit annealing,Manual

Boonzaier, L., Pauly, D., . 2016. Marine protection targets: an updated assessment of global progress. Oryx 50 (1), 27-35. https://doi.org/10.1017/S0030605315000848.

Butchart, S.H., Walpole, M., Collen, B., Van Strien, A., Scharlemann, J.P., Almond, R.E., et al., . 2010. Global biodiversity: indicators of recent declines. Science 328 (5982), 1164-1168. https://doi.org/10.1126/science.1187512.

Butchart, S.H.M., Scharlemann, J.P.W., Evans, M.I., Quader, S., Aricò, S., Arinaitwe, J., et al., . 2012. Protecting important sites for biodiversity contributes to meeting global conservation targets. PLoS ONE 7 (3) e32529, https://doi.org/10.1371/journal.pone. 0032529.

Cancun Declaration, . 2002. Cancun Declaration of Like-minded Megadiversity Countries. Available at: https://www.environment.gov.za/sites/default/files/docs/cancun lmmc_declaration1.pdf

Carvalho, S.B., Brito, J.C., Crespo, E.G., Watts, M.E., Possingham, H.P., . 2011. Conservation planning under climate change: toward accounting for uncertainty in predicted pecies distributions to increase confidence in conservation investments in space and time. Biol. Conserv. 144,2020-2030, https://doi.org/10.1016/j.biocon.2011.04.024.

CNUC/MMA (Cadastro Nacional de Unidades de Conservaço/Ministério do Meio Ambiente), . 2018. Unidades de conservação por biomaAvailable at: http://www.mma.gov. br/areas-protegidas/cadastro-nacional-de-ucs/dados-consolidados

CBD ( Convention on Biological Diversity), 2010. Strategic Plan for Biodiversity 2011-2020, Including Aichi Biodiversity Targets Available at: http://www.cbd.int// sp/elements/

Diegues, A.C.,. 1999. Human populations and coastal wetlands: conservation and management in Brazil. Ocean. Coast Manag. 42, 187-210, https://doi.org/10.1016/ S0964-5691(98)00053-2.

NOAA/ESRL (National Oceanic and Atmospheric Administration/Earth System Research Laboratory), 2017. Available at: https://www.esrl.noaa.gov/gmd/ccgg/trends/global. html/(accessed January 2017).

Dupont, S., Havenhand, J., Thorndyke, W., Peck, L., Thorndyke, M., . 2008. Near-future level of $\mathrm{CO}_{2}$-driven ocean acidification radically affects larval survival and development in the brittlestar Ophiothrix fragilis. Mar. Ecol. Prog. Ser. 373, 285-294. https: //doi.org/10.3354/meps07800.

Dupont, S., Ortega-Martinez, O., Thorndyke, M., . 2010. Impact of near-future ocean acidification on echinoderms. Ecotoxicology 19449-462. https://doi.org/10.1007/ s10646-010-0463-6.

Dutra, G.F., Camargo, E., Santos, C.A.P., Ceotto, P., . 2011. Abrolhos: desafios para a conservação e o desenvolvimento sustentável na área com a maior biodiversidade marinha do Atlântico Sul. Field Actions Science Reports3-6.

Eisenlord, M.E., Groner, M.L., Yoshioka, R.M., Elliot, J., Maynard, J., Fradkin, S., et al., 2016. Ochre star mortality during the 2014 wasting disease epizootic: role of population size structure and temperature. Philos. Trans. R. Soc. Lond. B Biol. Sci. 371 (1689)20150212, https://doi.org/10.1098/rstb.2015.0212.

Elith, J., Leathwick, J.R., . 2009. The contribution of species distribution modelling to conservation prioritization. In: Moilanen, A., Wilson, K.A., Possingham, H.P. (Eds.), Spatial Conservation Prioritization: Quantitative Methods and Computational Tools. Oxford University Press, Oxford, UK, pp. 70-92.

Ferreira, J., Aragão, L.E.O.C., Barlow, J., Barreto, P., Berenguer, E., Bustamante, M., et al., . 2014. Brazil's environmental leadership at risk. Science 346 (6210), 706-707. https: //doi.org/10.1126/science.1260194.

Gerhardinger, L.C., Godoy, E.A.S., Jones, P.J.S., Sales, G., Ferreira, B.P., . 2011. Marine protected dramas: the flaws of the Brazilian national system of marine protected areas. Environ. Manag. 47, 630-643. https://doi.org/10.1007/s00267-010-9554-7.

Guisan, A., Wilfried, T., . 2005. Predicting species distribution: offering more than simple habitat models. Ecol. Lett. 8, 993-1009. https://doi.org/10.1111/j.1461-0248.2005. 00792.x.

Halpern, B.S., . 2008. A global map of human impact on marine ecosystems. Science 319, 948-953. https://doi.org/10.1126/science.1149345.

Halpern, B.S., Frazier, M., Potapenko, J., Casey, K.S., Koening, K., Longo, C., Lowndes, J.S., Rockwood, R.C., Seling, E.R., Selkoe, K.A., Walbridge, S., . 2015. Spatial and temporal changes in cumulative human impacts on the world's ocean. Nature7615. https: //doi.org/10.1038/ncomms8615.

Hannah, L., Midgley, G., Andelman, S., Araújo, M., Hughes, G., Martinez-Meyer, E., Pearson, R., Williams, P., . 2007. Protected area needs in a changing climate. Front. Ecol. Environ. 5, 131-138. https://doi.org/10.1890/1540-9295(2007)5[131:PANIAC]2.0. $\mathrm{CO} ; 2$.

Harley, C.D.G., Hughes, A.R., Hultgren, K.M., Miner, B.G., Sorte, C.J.B., Thornber, C.S., et al., . 2006. The impacts of climate change in coastal marine systems. Ecol. Lett. 9 (2)228-241. https://doi.org/10.1111/j.1461-0248.2005.00871.x.

Heikkinen, R.K., Luoto, M., Araújo, M.B., Virkkala, R., Thuiller, W., Sykes, M.T., . 2006. Methods and uncertainties in bioclimatic envelope modelling under climate change. Prog. Phys. Geogr. 30, 751-777. https://doi.org/10.1177/0309133306071957.

Hernandez, P.A., Graham, C.H., Master, L.L., Albert, D.L., . 2006. The effect of sample size and species characteristics on performance of different species distribution modeling methods. Ecography 5773-785. https://doi.org/10.1111/j.0906-7590.2006.04700.x.

Hoegh-Guldberg, O., Bruno, J.F., . 2010. The impact of climate change on the world's marine ecosystems. Science 328 (5985)1523-1528. https://doi.org/10.1126/science. 1189930.
Hortal, J., de Bello, F., Diniz-Filho, J.A., Lewinsohn, T.M., Lobo, J.M., et al., . 2015. Seven shortfalls that beset large-scale knowledge of biodiversity. Annu. Rev. Ecol. Evol Syst. 46,523-549, https://doi.org/10.1146/annurev-ecolsys-112414-054400.

Hughes, L., . 2000. Biological consequences of global warming: is the signal already apparent?. Trends Ecol. Evol. 15, 56-61. https://doi.org/10.1016/S0169-5347(99)01764-4.

IPCC (Intergovernmental Panel on Climate Change), . 2000. Emission Scenarios. Summary for Policymakers. A Special Report of IPCC Working Group III. IPCC, Geneva, Switzerland

IPCC (Intergovernmental Panel on Climate Change, 2014. . Climate Change 2014: Synthesis Report. Contribution of Working Groups I, II and III to the Fifth Assessment Report of the Intergovernmental Panel on Climate Change. IPCC, Geneva, Switzerland

IUCN (International Union for Conservation of Nature), . 2014. World Park Congress, Available at: https://portals.iucn.org/congress/motion/053

Knight, A.T., Cowling, R.M., Rouget, M., Balmford, A., Lombard, A.T., et al., . 2008. Knowing but not doing: selecting priority conservation areas and the research-implementation gap. Conserv. Biol. 22, 610-617.

Kujala, H., Moilanen, A., Araújo, M.B., Cabeza, M., . 2013. Conservation planning with uncertain climate change projections. PLoS ONE 8 (2)e53315, https://doi.org/10.1371/ journal.pone. 0053315 .

Kumar, S., Stohlgren, T.J., . 2009. Maxent modeling for predicting suitable habitat for threatened and endangered tree Canacomyrica monticola in New Caledonia. J. Ecol. Nat. Sci. 1,094-098.

Lehtomäki, J., Moilanen, A., Toivonen, T., Leathwick, J., . 2016. Running a Zonation Planning Project. Available at: http://cbig.it.helsinki.fi/files/zonation/running_zproject v1_0_web.pdf

Lemes, P., Loyola, R.D., . 2013. Accommodating species climate-forced dispersal and uncertainties in spatial conservation planning. PLoS ONE 8 (1)e54323, https://doi.org/ 10.1371/journal.pone.0054323.

Lima, M.H.P., Rodrigues, C.M., Silva, J.K.T., Martins, P.C., Terron, S.L., Silva, R.L.S., 2002. Divisão Territorial Do Brasil. Fundação Instituto Brasileiro de Geografia e Estatística.

Lomolino, M.V., Heaney, L.R., . In: 2004. , Frontiers of Biogeography: New Directions in the Geography of Nature. Sinauer Associates, Inc. Publishers, Sunderland, Massachusettspp.

Loyola, R.D., Lemes, P., Nabout, J.C., Trindade-Filho, J., Sagnori, M.D., Dobrovolski, R., et al., . 2013. A straightforward conceptual approach for evaluating spatial conservation priorities under climate change. Biodiver. Conserv. 22, 483-495. https://doi.org/10. 1007/s10531-012-0424-x

Magris, R.A., Déstro, G.F.G., . 2010, Predictive modelling of suitable habitats for threatened marine invertebrates and implications for conservation assessment in Brazil. Braz. J. Oceanogr. 58, 57-68, https://doi.org/10.1590/S1679-87592010000800008.

Magris, R.A., Mills, M., Fuentes, M.M.P.B., Pressey, R.L., . 2013. Analysis of progress towards a comprehensive system of marine protected areas in Brazil. NatConserv 11, 81-87, https://doi.org/10.4322/natcon.2013.013.

Margules, C.R., Pressey, R.L., . 2000. Systematic conservation planning. Nature 405, 243-253. https://doi.org/10.1038/35012251.

Mascia, M.B., Pailler, S., . 2011. Protected area downgrading, downsizing, and degazettement (PADDD) and its conservation implications. Conserv. Lett. 4 (1), 9-20, http:// www.nature.com/news/2011/111109/full/479160a/box/1.html.

Mascia, M.B., Pailler, S., Krithivasan, R., . 2012. PADDDtracker.org Technical Guide.World Wildlife Fund, Washington, D.C., USA. Available at: http://www.padddtracker.org/ sites/default/files/PADDDtrackerTechnicalGuidev12012-09-03.pdf

Mazor, T., Possingham, H.P., Edelist, D., Brokovich, E., Kark, S., 2014. The crowded sea: incorporating multiple marine activities in conservation plans can significantly alter spatial priorities. PLOS ONE 9 (8)e104489, https://doi.org/10.1371/journal.pone 0104489.

McLeod, E., Salm, R., Green, A., Almany, J., . 2009. Designing marine protected area networks to address the impacts of climate change. Front. Ecol. Environ. 7, 362-370.

Menge, B.A., Cerny-Chipman, E.B., Johnson, A., Sullivan, J., Gravem, S., Chan, F., . 2016. Sea star wasting disease in the keystone predator Pisaster ochraceus in Oregon: in sights into differential population impacts, recovery, predation rate, and temperature effects from long-term research. PLoS ONE 11, e0153994, pmid:27144391.

Mills, L.S., Soulé, M.E., Doak, D.F., . 1993. The keystone-species concept in ecology and conservation. BioScience 43 (4),219-224, https://doi.org/10.2307/1312122.

Miloslavich, P., Klein, E., Díaz, J.M., Hernández, C.E., Bigatti, G., Campos, L., et al., . 2011 Marine biodiversity in the Atlantic and Pacific coasts of South America: knowledge and gaps. PLoS ONE 6 (1) e14631, https://doi.org/10.1371/journal.pone.0014631.

MMA (Ministério do Meio Ambiente), . 2008. Livro vermelho da fauna ameaçada de extinção

MMA (Ministério do Meio Ambiente), 2017. Download de dados geográficos. Available at http://mapas.mma.gov.br/i3geo/datadownload.htm/(accessed June 2017).

MMA (Ministério do Meio Ambiente), 2018. Plano de Manejo. Available at: http://www. mma.gov.br/areas-protegidas/unidades-de-conservacao/plano-de-manejo /(accessed January 2018)

Moilanen, A., Pouzols, F.M., Meller, L., Veach, V., Arponen, A., Leppänen, J., et al., . 2014. Spatial Conservation Planning Methods and Software Zonation. User Manual.

Monllor-Hurtado, A., Pennino, M.G., Sanchez-Lizaso, J.L., . 2017. Shift in tuna catches due to ocean warming. PLoS ONE 12 (6)e0178196, https://doi.org/10.1371/journal.pone. 0178196.

Montecino-Latorre, D., Eisenlord, M.E., Turner, M., Yoshioka, R., Harvell, C.D., Pat tengill-Semmens, C.V., et al., . 2016. Devastating transboundary impacts of sea star wasting disease on subtidal asteroids. PLoS ONE 11e0163190, pmid:27783620.

NOAA (National Geophysical Data Center), . 1988. Digital Relief of the Surface of the Earth. NOAA, Boulder, Colorado .Available at: https://www.ngdc.noaa.gov/mgg/ global/etopo5.HTML 
O'Leary, B.C., Janson, M.W., Bainbridge, J.M., Aitken, J., Hawkins, J.P., Roberts, C.M., 2016. Effective coverage targets for ocean protection. Conserv. Lett. 9,398-404. https: //doi.org/10.1111/conl.12247.

Papes, M., Gaubert, P., . 2007. Modelling ecological niches from low numbers of occurrences: assessment of the conservation status of poorly known viverrids (Mammalia, Carnivora) across two continents. Divers Distrib. 13,890-902. https://doi.org/ 10.1111/j.1472-4642.2007.00392.x.

Parmesan, C., . 2006. Ecological and evolutionary responses to recent climate change. Annu. Rev. Ecol. Evol Syst. 37637-669, https://doi.org/10.1146/annurev.ecolsys.37. 091305.110100.

Pearson, R.G., Dawson, T.P., . 2003. Predicting the impacts of climate change on the distribution of species: are bioclimate envelope models useful?. Glob. Ecol. Biogeogr. 12, 361-371,https://doi.org/10.1046/j.1466-822X.2003.00042.x.

Pearson, R.G., Raxworthy, C.J., Nakamura, M., Peterson, A.T., . 2007. Predicting species distributions from small numbers of occurrence records: a test case using cryptic geckos in Madagascar. J. Biogeogr. 34102-117. https://doi.org/10.1111/j. 1365-2699.2006. 01594.x.

Perry, A.L., Low, P.J., Ellis, J.R., Reynolds, J.D., . 2005. Climate change and distribution shifts in marine fishes. Science 308 (5730),1912-1915. https://doi.org/10.1126/ science. 1111322.

Peterson, A.T., Soberón, J., Pearson, R.G., Anderson, R.P., Martınez-Meyer, E., Nakamura, M., et al., . 2011. Ecological niches and geographic distributionsPrinceton University Press, Princeton, New Jersey, USA.

Phillips, S.J., Anderson, R.P., Schapire, R.E., . 2006. Maximum entropy modeling of species geographic distributions. Ecol. Modell. 190,231-259, https://doi.org/10.1016/j. ecolmodel.2005.03.026.

Pimm, S.L., Jenkins, C.N., Abell, R., Brooks, T.M., Gittleman, J.L., Joppa, L.N., Raven, P.H., Roberts, C.M., Sexton, J.O., . 2014. The biodiversity of species and their rates of extinction, distribution and protection. Science 344 (6187), 1246752, https://doi.org/ $10.1126 /$ science. 1246752 .

Poloczanska, E.S., Burrows, M.T., Brown, C.J., Molinos, J.C., Halpern, B.S., et al., . 2016. Response of marine organisms to climate change across oceans. Front. Mar. Sci. 3,62, https://doi.org/10.3389/fmars.2016.00062.

Porfirio, L.L., Harris, R.M.B., Lefroy, E.C., Hugh, S., Gould, S.F., Lee, G., et al., . 2014. Improving the use of species distribution models in conservation planning and management under climate change. PLoS ONE 9 (11)e113749, https://doi.org/10.1371/ journal.pone.0113749.

Pressey, R.L., Watts, M.E., Barret, T.W., Ridges, M.J., . 2009. The C-Plan conservation planning system: origins, applications, and possible futures. In: Moilanen, A., Wilson, K.A., Possingham, H.P. (Eds.), Spatial Conservation Prioritization: Quantitative Methods and Computational Tools. Oxford University Press, Oxford, UK, pp. pp. 211-234.

Ramsar. Ramsar Convention Secretariat, . 2016. The Fourth Ramsar Strategic Plan 2016-2024. Ramsar handbooks for the wise use of wetlandsRamsar Convention Secretariat, Gland, Switzerland

Rocchini, D., Hortal, J., Lengyel, S., Lobo, J.M., Jimenez-Valverde, A., et al., . 2011. Accounting for uncertainty when mapping species distributions: the need for maps of ignorance. Prog. Phys. Geogr. 35211-226.
Rodriguez, J.P., Brotons, L., Bustamante, J., Seoane, J., . 2007. The application of predictive modelling of species distribution to biodiversity conservation. Divers Distrib. 13243-251. https://doi.org/10.1111/j.1472-4642.2007.00356.x.

Sanford, E.,. 1999. Regulation of keystone predation by small changes in ocean temperature. Science 283, 2095-2097.

Schiavetti, A., Manz, J., Santos, C., Magro, T., Pagani, M., . 2013. Marine protected areas in Brazil: an ecological approach regarding the large marine ecosystems. Ocean. Coast Manag. 7696-104, https://doi.org/10.1016/j.ocecoaman.2013.02.003.

Selig, E.R., Turner, W.R., Troëng, S., Wallace, B.P., Halpern, B.S., Kaschner, K., et al., 2014. Global priorities for marine biodiversity conservation. PLoS ONE 9 (1), e82898, https://doi.org/10.1371/journal.pone.0082898.

Soares, M.O., Paiva, C.C., Freitas, J.E.P., Lotufo, T.M.C., . 2011. Gestão de unidades de conservação marinhas: o caso do Parque Estadual Marinho da Pedra da Risca do Meio, NE - Brasil. J. Integr. Coast. Zone Manag. 11 (2), 257-268.

Sorte, C.J.B., Williams, S., Carlton, J.T., . 2010. Marine range shifts and species introductions: comparative spread rates and community impacts. Glob. Ecol. Biogeogr. 19,303-316. https://doi.org/10.1111/j.1466-8238.2009.00519.x.

Soulé, M.E., Sanjayan, M.A., . 1998. Conservation targets: do they help?. Science 279 (5359), 2060-2061. https://doi.org/10.1126/science.279.5359.2060.

Spínola, J.L., Teixeira, C.F., Andriguetto Filho, J.M., . 2014. Desafios à cogestão: os impactos da via Expressa Sul sobre o extrativismo na RESEX Marinha do Pirajubaé. Desenvolv. Meio Ambiente 32,139-150. https://doi.org/10.5380/dma.v32i0.35694

Terribile, L., Lima-Ribeiro, M., Araújo, M.B., Bizão, N., Collevatti, R., Dobrovolski, R., et al., . 2012. Areas of climate stability of species ranges in the Brazilian cerrado: disentangling uncertainties through time. Nat. Conserv. 10, 152-159, https://doi.org/10. 4322/natcon.2012.025.

Tyberghein, L., Verbruggen, H., Pauly, K., Troupin, C., Mineur, F., De Clerck, O., . 2012 Bio-ORACLE: a global environmental dataset for marine species distribution modelling. Glob. Ecol. Biogeogr. 21, 272-281. https://doi.org/10.1111/j.1466-8238.2011. 00656.x.

UNEP-WCMC and IUCN, 2016. Protected Planet Report 2016 , Cambridge UK and Gland, Switzerland Available at: https://wdpa.s3.amazonaws.com/Protected_Planet_Reports/ 2445\%20Global\%20Protected\%20Planet\%202016_WEB.pdf

Vilar, C.R., Joyeux, J.C., Loyola, R., Spach, H.L.,. 2015. Setting priorities for the conservation of marine vertebrates in Brazilian waters Ocean. Coast Manag. 107, 28-36, https: //doi.org/10.1016/j.ocecoaman.2015.01.018.

Wahrlich, R., 1999. A. reserva biológica marinha do Arvoredo (SC) e a atividade pesqueira regional M.Sc. Thesis. Universidade Federal de Santa Catarina, Centro de Filosofia e Ciências Humanas Available at: http://repositorio.ufsc.br/xmlui/handle/123456789/ 80889

Wisz, M.S., Hijmans, R.J., Li, J., Peterson, A.T., Graham, C.H., Guisan, A.. 2008. Effects of sample size on the performance of species distribution models Divers Distrib. 14,763-773. https://doi.org/10.1111/j.1472-4642.2008.00482.x. 